\title{
Imágenes operativas y montaje blando: historicidad de la función social de la imagen en la obra de Harun Farocki ${ }^{1}$
}

\section{Operative images and soft-montage, or the historicity of the social function of images in the work of Harun Farocki}

\section{Claudio Celis Bueno}

Facultad de Arquitectura, Arte y Diseño, Universidad Diego Portales. Santiago, Chile. claudio.celis@mail.udp.cl

\section{Resumen}

El presente texto examina las nociones de imágenes operativas y de montaje blando en las video-instalaciones de Harun Farocki para proponer que el valor crítico de su obra consiste en el despliegue de una reflexión sistemática sobre la historicidad de la función social de la imagen. Por lo tanto, la obra de Farocki propone que en el mundo contemporáneo la función social de la representación visual está marcada por el tránsito desde un régimen de la imagen a lo que ha sido denominado como régimen de la visualidad.

Palabras clave: Farocki, imagen, poder, dispositivo, metraje-encontrado, montaje.

\begin{abstract}
This paper examines the notions of operative images and soft-montage in order to better understand the critical value of Harun Farocki's video installations. This paper puts forth the following hypothesis: the critical value of Farocki's work lies on its capacity to reflect upon the historicity of the social function of images. More specifically, Farocki's work suggests that in the contemporary world the social function of visual representation shifts from the regime of images to what has been defined as the visuality regime.
\end{abstract}

Keywords: Farocki, Image, Power, Apparatus, Found-Footage, Montage.

1 Este artículo fue escritoen el marco del proyecto FONDECYT de postdoctorado "Estética y política del cine de metraje encontrado" ( $\left.\mathrm{N}^{\circ} 3160053\right)$ 


\section{Introducción}

En un breve texto sobre Harun Farocki, David Rodowick sugiere que "lo más básico, pero a la vez lo más acertado, que uno puede decir sobre el trabajo de Farocki es que es el resultado de una vida consagrada a la crítica de las imágenes a través de las imágenes" $(191)^{2}$. Por cierto, cada uno de sus trabajos pone en marcha un análisis sobre el "campo de relaciones de fuerzas que producen, desconectan y recombinan las imágenes en la actualidad" y que no deja de plantearnos, una y otra vez, la misma pregunta: “qué es una imagen?” (Rodowick 191). De modo similar, David Tomas sugiere que la obra de Farocki contribuye a la construcción de una historia de las relaciones entre la imagen, la mirada y la máquina (7). Además, señala que desarrolla una investigación sistemática acerca del proceso de constitución de una visión maquínica que reemplaza gradualmente al ojo humano, incluso propone que las dos nociones más importantes para comprender esta historia de la mirada son las de imágenes operativas y de montaje blando (219).

En sintonía con las lecturas de Rodowick y Tomas, el presente texto examinará las nociones de imágenes operativas y de montaje blando con el fin de comprender el potencial crítico de la obra de Harun Farocki a partir de la siguiente hipótesis: el valor crítico de la obra de Farocki consiste en su capacidad para desplegar una reflexión sistemática sobre la historicidad que posee la función social de la imagen. En particular, la obra de Farocki propone que la función de social de la representación visual en el mundo contemporáneo está marcada por el tránsito desde un régimen de la imagen a lo que ha sido denominado como el régimen de la visualidad.

\section{Imágenes operativas}

Uno de los conceptos centrales para entender el trabajo audiovisual de Harun Farocki es el concepto de imágenes operativas. Según el propio Farocki, este concepto surgió del trabajo de investigación realizado para la video-instalación Eye/Machine (2001). Farocki escribe: "llamé 'imágenes operativas' a estas imágenes que no están hechas para entretener ni para informar. Imágenes que no buscan simplemente reproducir algo, sino que son más bien parte de una operación" (Desconfiar 153). Por lo tanto, una imagen operativa es un tipo de imagen cuya función principal es organizar una

2 Harun Farocki (1944-2014) fue un director de cine y video-artista alemán. Hijo de padres que migraron de India a Alemania en la década del veinte. Estudió cine en Berlín y desde los años setenta se dedicó a producir documentales y video-instalaciones que cuestionaban los límites de la representación, así como la dimensión política de la imagen. Para mayor información sobre la vida y obra de este autor alemán, véase la página web: www.harunfarocki. de. Para un análisis de su obra véanse los libros Harun Farocki: Against What? Against Whom, editado por Nora Alter (2009) y Harun Farocki: Working on the sightlines, editado por Thomas Elssaeser (2004). En relación a su recepción en Chile, véase Sobre Harun Farocki: La continuidad de la guerra a través de las imágenes, editado por Diego Fernández (2012). 
operación técnica específica, en vez de representar un objeto para su contemplación. Las imágenes operativas pueden ser utilizadas con fines de vigilancia, de examinación médica o como parte esencial de procesos industriales, militares o logísticos. Estas imágenes no implican necesariamente la presencia de un sujeto observador. Con la creación de algoritmos más avanzados y con el desarrollo de los procesos de automatización, se inicia una gradual independización de las imágenes operativas respecto de la presencia del ojo humano. Gracias a esta automatización, dichas imágenes ingresan en una edad caracterizada por aquello que Paul Virilio llamó "visión maquínica”3.

Una parte importante de la obra de Farocki se limita a la recopilación y reutilización de imágenes operativas. Desde la realización de su documental Cómo se ve (Wiemansieht) en 1986, comenzó a examinar las diversas tipologías de imágenes operativas que regulan nuestro modo de vida. De este modo, en documentales como Imágenes del mundo y la inscripción de la guerra (1989) e Imágenes de prisión (2000), pero principalmente en las video-instalaciones desarrolladas desde el año 2000 en adelante, su trabajo se define por la compilación de imágenes operativas provenientes de un gran número de instituciones (militares, médicas, logísticas, carcelarias) que luego son puestas en valor a través del trabajo de montaje, generalmente acompañadas con una voz en offo intertítulos. Precisamente, uno de los rasgos característicos de su obra radica en que la narración en off que acompaña a las imágenes operativas posee siempre un tono descriptivo, nunca normativo. Esto se debe al carácter inmanente que define la crítica de las imágenes por medio de imágenes que él desarrolla. Sin embargo, por ahora dejaremos a un lado la pregunta acerca del valor de la crítica inmanente puesta en marcha por sus trabajos. Volveremos sobre ello una vez que hayamos despejado las nociones de imágenes operatorias y montaje blando.

Harun Farocki declara que la noción de imagen operativa proviene de un desplazamiento hacia el campo de las imágenes de la noción de operatividad del lenguaje introducida por Roland Barthes en su análisis del carácter ideológico del mito (153). En su libro Mitologías, Barthes examina la noción de mito desde la diferenciación entre lenguaje-objeto y metalenguaje (241). El lenguaje-objeto refiere a cualquier sistema lingüístico de primer orden, por ejemplo, una lengua. El autor francés utiliza el término objeto porque es precisamente dicho sistema lingüístico de primer orden el cual constituye el objeto de un metalenguaje en la construcción de un mito. A partir de la semiología de Saussure, define el signo compuesto de un significante y un significado. De ese modo, en el mito, el signo de un sistema de primer orden (el lenguaje-objeto) deviene el significante de un sistema de segundo orden (205). Por ejemplo, la imagen publicitaria de una pasta y unos tomates constituye un signo compuesto de un significante (la fotografía de una pasta y unos tomates) y un significado

3 En la década del ochenta, Paul Virilio introdujo esta noción sugiriendo que ya en ese momento era posible imaginar el desarrollo de una mirada sin sujeto, una mirada automatizada por máquinas de percepción cuyo objeto serían imágenes creadas por máquinas para ser utilizadas e interpretadas por máquinas (59-62). 
(la pasta y los tomates). En el mito, este signo se convierte en el significante de otro significado (lo "italiano", por ejemplo). El mito transforma un lenguaje-objeto en un metalenguaje y con ello naturaliza un significado que de por sí es histórico. Dicho de manera esquemática y utilizando los conceptos del propio Roland Barthes, el mito consiste en la naturalización del carácter connotativo de un signo ${ }^{4}$.

Para explicar la distinción entre lenguaje-objeto y metalenguaje y desde allí examinar la posibilidad de un uso no ideológico del lenguaje, utiliza el ejemplo de un leñador:

Si soy un leñador y, como tal, nombro el árbol que derribo, cualquiera sea la forma de mi frase, hablo el árbol, no hablo sobre él. Esto quiere decir que mi lenguaje es operatorio, ligado a su objeto de manera transitiva: entre el árbol y yo lo único que existe es mi trabajo, es decir, un acto. Ése es un lenguaje político; me presenta la naturaleza sólo en la medida en que quiero transformarla, es un lenguaje mediante el cual yo actúo el objeto: el árbol no es para mí una imagen, es simplemente el sentido de mi acto. Pero si no soy leñador, ya no puedo hablar el árbol, sólo puedo hablar de él, sobre él. Mi lenguaje deja de ser el instrumento de un árbol actuado, ahora el árbol cantado se convierte en instrumento de mi lenguaje, sólo tengo con el árbol una relación intransitiva; el árbol no es más que el sentido de lo real como acto humano, es una imagen en disponibilidad: frente al lenguaje real del leñador, creo un lenguaje segundo, un metalenguaje, en el que voy a poner en acción no las cosas, sino sus nombres, y que es al lenguaje primero lo que el gesto es al acto. Este lenguaje segundo no es enteramente mítico, pero es el sitio exacto en el que se instala el mito, porque el mito sólo puede trabajar sobre objetos que ya han sufrido la mediación de un primer lenguaje (241-2).

Farocki refiere explícitamente al ejemplo del leñador de Barthes para ilustrar la diferencia entre las imágenes operativas y las imágenes no-operativas (153). Por un lado, las imágenes no-operativas refieren a un metalenguaje, es decir, se limitan a la representación de un objeto. Por lo tanto, las imágenes no-operativas inundan el mundo a través de los medios de comunicación de masa (cine, televisión, industria publicitaria, etc.), los cuales producen constantemente una "remitologización de lo cotidiano" (154). Por otro lado, existe toda una red de imágenes operativas que cada vez forman mayormente parte de los procesos técnicos que regulan la vida contem-

4 Es importante señalar que la distinción entre denotación y connotación fue considerada por Jean Baudrillard como el mito superior del lenguaje, es decir, aquel que naturaliza el proceso mismo de la ideología (187). Para Baudrillard (siguiendo al propio Barthes de $S / Z$ ), el valor denotativo de un signo no es más que la mayor sutileza de sus connotaciones, aquella en la cual el supuesto valor objetivo del signo depende de la borradura de "los rastros del proceso ideológico" y de la restitución de lo universal a través de la "inocencia objetiva” (187). Desde esta perspectiva, la distinción entre un uso mitológico y un uso no-mitológico del lenguaje sostenida por Barthes en Mitologías es denunciada por Baudrillard como el resultado de un proceso de remitologización del valor de uso (objetivo) del lenguaje. 
FIGURA 1

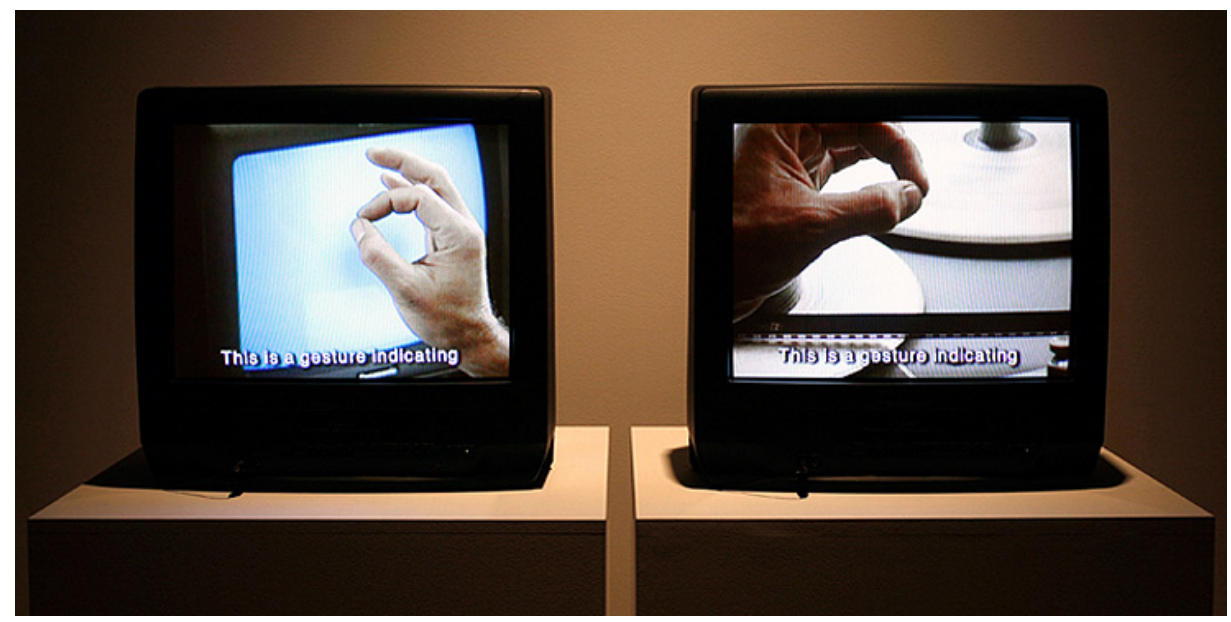

Interface, Harun Farocki. Video-instalación de proyección doble. 1995.

poránea. Estas imágenes no remiten a una dimensión semiológica ni mitológica, sino que funcionan como parte integral de un proceso técnico concreto.

Ahora bien, la referencia a Barthes y al ejemplo del leñador realizada por el propio Farocki no hace justicia a la potencia del término imágenes operativas ni a la importancia que adquiere al interior de su obra audiovisual. En primer lugar, el ejemplo de Barthes no explicita la relación entre el lenguaje-objeto y el acto mismo de cortar el árbol. Dicho de modo esquemático: (a) el acto de cortar el árbol no requiere que el leñador lo nombre como tal; (b) el lenguaje-objeto 'árbol' no forma parte del proceso operativo comprometido en el derribamiento de un árbol. A partir de esta constatación se podría decir, en contra de Barthes, que el discurso del leñador será siempre descriptivo, nunca operativo. En segundo lugar, el ejemplo de Barthes sigue tramado por la semiología, es decir, no puede concebir las imágenes más allá de su condición de signo y por ende más allá de su significado expresado (sea un significado denotativo o connotativo, objetivo o mitológico). En el caso de las imágenes operativas, se trata de imágenes que no describen un procedimiento sino que forman parte integral de este. Su análisis, por lo tanto, no puede reducirse al campo de la semiología (la imagen como signo): debe desplazarse hacia el análisis de los procedimientos concretos de los cuales forma parte.

La potencia del término imágenes operativas va mucho más lejos que el ejemplo dado por Barthes y recuperado por el propio Farocki. Dicho de otro modo, creo que, para comprender la potencia del trabajo de Farocki, el recurso a Barthes es insuficiente. Entonces, para avanzar en la comprensión del concepto de imágenes operativas propongo que lo interpretemos retomando otras dos perspectivas complementarias. Me refiero a la teoría del lenguaje de John Austin y al método de análisis de discurso de Michel Foucault. 
Alrededor del mismo año en que Barthes publicaba su ensayo sobre el mito, John Austin dictaba una serie de conferencias que hoy nos ofrecen una herramienta más pertinente para comprender la aplicabilidad e importancia del término imágenes operativas $^{5}$. En dichas conferencias, Austin introduce la hipótesis acerca del carácter "performativo" del lenguaje. Tradicionalmente, postula Austin, la lingüística ha considerado el discurso en tanto enunciado, es decir, como aquellas formulaciones lingüísticas que pueden ser juzgadas según su condición de verdadero o falso. Esto se sostiene sobre una antigua suposición filosófica: "la suposición de que decir algo, al menos en todos los casos dignos de ser considerados [...] es siempre enunciar algo" (53). Bajo esta premisa, el enunciado es analizado desde la perspectiva de su construcción gramatical y en función de si aquello que dicha construcción gramatical enuncia se adecua o no a la realidad que dice enunciar. A diferencia de este modo tradicional de comprender el discurso, Austin propone que existe una dimensión del lenguaje en la cual decir algo consiste en hacer algo. Para distinguirlo del uso descriptivo o constatativo del enunciado, Austin utiliza el término de performativo (o realizativo) ${ }^{6}$. El acto performativo de lenguaje "no describe o registra nada" ni puede ser evaluado en términos de "verdadero o falso"; por el contrario, "el acto de expresar la oración es realizar una acción, o parte de ella" (45). Uno de los ejemplos que ofrece Austin es el acto realizado al decir "yo te prometo". En este caso, el sujeto que enuncia esta frase no describe una acción, sino que la realiza: la expresión es simultáneamente su realización. Lo mismo aplicaría para frases como "yo juro", “yo te bautizo", etc.

Para analizar la dimensión performativa del lenguaje no basta con analizar su contenido gramatical (ya que su función no depende de su valor de veracidad): es necesario comprender los procedimientos que hacen de un acto lingüístico parte integral de una acción (Austin 56). Más aun, podemos decir que es el carácter performativo de un acto de lenguaje el que, en cada caso, produce al sujeto de la enunciación. Toda expresión performativa depende de un procedimiento que a su vez define el acto realizado y la posición del sujeto que lo lleva a cabo. Por ejemplo, en el caso de la expresión "yo te bautizo", la acción es realizada sólo mientras quien la enuncie sea reconocido en su posición de autoridad (un cura o sacerdote) y que su enunciación responda a un procedimiento institucional específico (el bautizo cristiano). De igual modo, la expresión performativa determina la posición de sujeto de todos los involucrados en la realización de la acción (el cura o sacerdote, el niño bautizado, los padres y padrinos del niño, etc.).

La hipótesis de Austin es de gran utilidad para comprender el concepto de imágenes operativas en Farocki. Al igual que las expresiones performativas, las imágenes operativas no significan ni describen, sino que forman parte integral de un meca-

5 Estas doce conferencias fueron dictadas por John Austin en la Universidad de Harvard en 1955 y han sido publicadas bajo el título Cómo hacer cosas con palabras.

6 El término proviene del inglés "performative". En la traducción española aparece como "realizativo". 
nismo que realiza un acto. Tomemos por ejemplo una de las imágenes operativas más canónicas de la obra de Farocki: las imágenes de prisión. En este caso, la imagen producida por una cámara de vigilancia no describe un comedor, un pasillo, una celda o una pelea, consiste en la realización inmediata del acto de vigilar. Podemos decir que el concepto de expresión performativa de Austin se adecua mejor a la noción de imagen operativa que la distinción entre lenguaje-objeto y metalenguaje ofrecida por Barthes. En el ejemplo de Barthes, existe un supuesto vínculo entre el acto de nombrar el árbol y el acto de derribarlo. Pero como ya mencionábamos, nombrar el árbol no forma parte de dicho acto. Por el contrario, una expresión performativa -en el sentido que le otorga Austin- refiere exclusivamente a aquellas expresiones que son inmediatamente la realización de una acción u operación ${ }^{7}$. Lo mismo podemos decir de las imágenes operativas: son imágenes que no representan un objeto, sino forman parte de un procedimiento técnico que realiza una acción determinada. Así, en el ejemplo de las imágenes de prisión, es correcto decir que el objeto analizado por Farocki no es el sujeto vigilado (el contenido referencial de la imagen) sino el rol de las imágenes en el sistema mismo de vigilancia (Blumenthal-Barby 132).

La referencia a la teoría sobre el carácter performativo del lenguaje en Austin nos permite conectar el concepto de imágenes operativas con el trabajo de otro autor al cual Farocki refiere continuamente, Michel Foucault ${ }^{8}$. En una conferencia dictada en 1972 en Río de Janeiro, titulada La verdad y las formas jurídicas, Foucault ofrece una reflexión metodológica sobre el tipo de análisis de discurso detrás de su trabajo. Como parte de dicha reflexión, refiere explícitamente al trabajo de Austin, sosteniendo que su manera de entender el análisis de discurso es deudora en gran parte de la filosofía analítica angloamericana (15). El argumento de Foucault es que la teoría acerca del carácter performativo del lenguaje hace posible romper con el análisis lingüístico de los enunciados que ha dominado el campo filosófico. Con ello, busca hacer visibles las relaciones de poder que en cada caso constituyen un acto de lenguaje. Foucault escribe:

7 Es significativo notar que, para definir estas expresiones, Austin sugiere que el único término imaginable es el de actos "operativos" de lenguaje: "la palabra que más se aproxima a lo que necesitamos es, quizás, el término técnico inglés operative en el sentido estricto que le dan los abogados para eludir a aquellas cláusulas de un instrumento que sirven para realizar la transacción (transferencia de un inmueble o lo que sea)" (48). El problema, sin embargo, es que la noción inglesa operative "tiene otras acepciones, y hoy en día se usa a menudo para significar poco más que 'eficaz' o 'conducente"' (48). Por esta razón, Austin prefiere un término neutro como performativo, en el sentido literal de la "realización de una acción" (47).

8 Otro autor que refiere explícitamente al trabajo de John Austin en relación al problema metodológico en el análisis de discurso es Jean François Lyotard en La condición postmoderna. Respecto al método elegido para analizar el estatuto del saber en las sociedades postindustriales, Lyotard escribe: "hemos preferido un procedimiento: el de poner el acento sobre los actos de habla, y dentro de esos actos, sobre su aspecto pragmático" (25). A la luz de este procedimiento, Lyotard realiza tres observaciones: a) las reglas de todo acto de lenguaje no tienen su legitimación en ellas mismas sino en un elemento externo; b) sin reglas no hay acto o juego de lenguaje; c) una modificación de una regla modifica la naturaleza del acto o juego de lenguaje (27). Lo interesante en el caso de Lyotard es el vínculo entre naturaleza operativa del lenguaje y sociedades postindustriales. Como veremos, en la obra de Harun Farocki la noción de imágenes operativas como método de investigación visual responde al mismo vínculo con un contexto postindustrial de producción. Mientras Lyotard analiza la condición postmoderna del saber en el contexto de una sociedad postindustrial, Farocki analiza la condición operativa que las imágenes adquieren en dicha sociedad. 


\title{
FIGURA 2
}

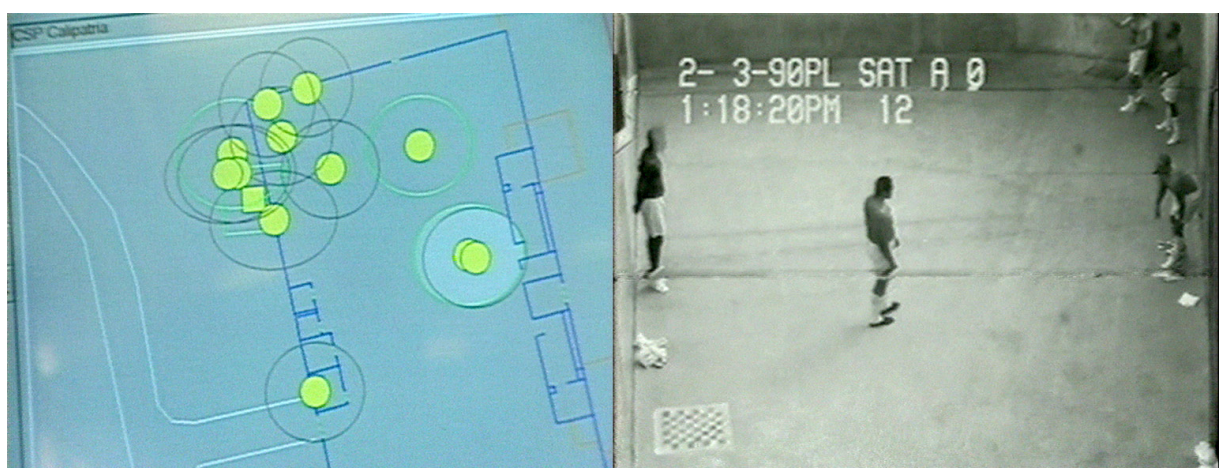

I Thought I Was Seeing Convicts, Harun Farocki. Video-instalación de proyección doble. 2001.

\begin{abstract}
Hace algunos años era original e importante decir y mostrar que aquello que se hacía con el lenguaje - poesía, literatura, filosofía, discurso en general- obedecía a un cierto número de leyes o regularidades internas: las leyes o regularidades del lenguaje. El carácter lingüístico de los hechos del lenguaje fue un descubrimiento que tuvo su importancia en determinada época (15).
\end{abstract}

Pese a la importancia de este descubrimiento, sin embargo, sostiene que hoy se hace necesario "considerar estos hechos del discurso ya no simplemente por su aspecto lingüístico sino, en cierto modo [...] como juegos estratégicos de acción y reacción, de preguntas y respuestas, de dominación y retracción, y también de lucha. El discurso es ese conjunto regular de hechos lingüísticos en determinado nivel, y polémicos y estratégicos en otro" (15). Para Foucault, lo importante no es analizar el discurso como una abstracción sino en tanto elemento concreto al interior de una relación de poder 9 . Tal como mencionábamos, el autor francés admite su deuda con el trabajo analítico de John Austin. Más aun, su argumento nos permite agregar un aspecto clave a nuestra definición de las imágenes operativas: el vínculo interno con un diagrama de poder. En Farocki, las imágenes operativas aparecen siempre al interior de un aparato institucional. En este sentido, las imágenes operativas funcionan siempre como parte de una red de relaciones de fuerza que da forma y administra determinados cuerpos y determinadas subjetividades. Cuando se dice que Farocki desarrolla una "crítica de las imágenes a través de las imágenes" debemos comprender que dicha crítica no se limita a la dimensión estética de la imagen (el equivalente al análisis lingüístico del discurso denunciado por Foucault), sino que debe incorporar el análisis de las

9 De modo similar, Lyotard explica que todo análisis de discurso debe considerar el principio fundamental según el cual "hablar es combatir, en el sentido de jugar, y que los actos de lenguaje se derivan de una agonística general" (27). 
instituciones y del campo de relaciones de fuerza que las "producen, desconectan y recombinan" (Rodowick 191). Esto es precisamente lo que define la singularidad de la noción de imagen operativa en el trabajo de Farocki.

Ahora bien, el giro desde el análisis lingüístico hacia el análisis del discurso como juego estratégico en Michel Foucault responde a un giro metodológico más general que intenta reconstruir la historia del sujeto, es decir, reconstruir la historia de los mecanismos de producción de subjetividad (La verdad 16). Por esta razón, Foucault se distancia explícitamente de la noción marxista de ideología en tanto engaño o falsa conciencia:

Llegamos así a esta noción muy importante, y al mismo tiempo muy embarazosa, de ideología. En los análisis marxistas tradicionales la ideología es presentada como una especie de elemento negativo a través del cual se traduce el hecho de que la relación del sujeto con la verdad, o simplemente la relación de conocimiento, es perturbada, oscurecida, velada por las condiciones de existencia, por las relaciones sociales o formas políticas impuestas, desde el exterior, al sujeto de conocimiento (32).

Para Foucault, la noción de ideología aparece en tanto velo de ilusión o engaño que impide al sujeto de conocimiento acceder a la verdad, como si dicho acceso estuviese asegurado a priori (y que es solo por causa de las relaciones sociales y económicas que dicho principio es perturbado y obstaculizado). En contra de la noción de ideología, Foucault se propone demostrar que "de hecho las condiciones políticas y económicas no son un velo o un obstáculo para el sujeto de conocimiento sino aquello a través de lo cual se forman los sujetos de conocimiento y, en consecuencia, las relaciones de verdad" (32).

Lo mismo podemos decir de la obra de Farocki. En ella, el poder político de una imagen nada tiene que ver con un problema de ideología, engaño o falsa conciencia. Por el contrario, las imágenes son presentadas en su condición operativa, es decir, como parte central de los procedimientos de producción de subjetividad. De este modo, el análisis de las imágenes en Farocki parte de la base de que toda imagen operativa pertenece siempre a un sistema de producción determinado, en el cual una imagen cumple una función técnica concreta. Las imágenes operativas no funcionan a través de la ideología (el engaño de un sujeto de conocimiento) sino que son ellas mismas las que posibilitan la producción de diversas subjetividades y del saber acerca de dichas subjetividades. Sean imágenes de vigilancia, de uso médico o militares, las imágenes operativas posibilitan tanto un nuevo saber respecto al sujeto como un perfeccionamiento de la aplicación del poder sobre dicho sujeto ${ }^{10}$. Así, en Imágenes

10 En Vigilar y castigar, Foucault examina esta doble relación entre saber y poder. Foucault escribe que gracias al panoptismo, "formación de saber y aumento de poder se refuerza regularmente según un proceso circular" (227). De este modo, la disciplina permite "un desbloqueo epistemológico a partir de un afinamiento de las relaciones 
de prisión, Farocki nos muestra cómo las imágenes utilizadas para ejercer la vigilancia al interior de la prisión se convierten en un nuevo mecanismo técnico capaz de analizar el comportamiento de los consumidores en los pasillos de un supermercado.

La crítica a la noción de ideología y su desplazamiento hacia el concepto de imágenes operativas en Farocki nos permite volver al ejemplo utilizado por Barthes a la hora de definir el carácter operativo del lenguaje. Para este último, la distinción entre lenguaje-objeto y metalenguaje era necesaria para sostener la posibilidad de un uso no-ideológico (no-mitológico) del lenguaje: "el lenguaje del hombre productor" (242). Según Barthes, "toda vez que el hombre habla para transformar lo real y no para conservar lo real como imagen, cuando liga su lenguaje a la elaboración de cosas, el metalenguaje es devuelto a un lenguaje-objeto, y el mito es imposible" (242). El método de Foucault se ubica en el extremo opuesto al de Barthes. Para él, suponer la posibilidad de un uso no ideológico del discurso exige admitir que el sujeto de conocimiento es anterior a sus propias condiciones de producción. Por el contrario, Foucault quiere demostrar que el sujeto de conocimiento es el resultado de un proceso de producción que es en sí mismo histórico y que involucra siempre relaciones concretas de poder.

Desde esta perspectiva, el trabajo de Farocki (y su noción de imágenes operativas) aparece como una reflexión sistemática acerca del rol de las imágenes en los procesos de constitución del sujeto contemporáneo. Tal como en el análisis de discurso, puesto en marcha por Austin y retomado por Foucault, el análisis de las imágenes llevado a cabo por Farocki explora el uso estratégico de las imágenes, su aplicación para un mecanismo de producción determinado, tramado siempre por un diagrama de poder específico. En sus documentales, la pregunta acerca de la imagen se corresponde siempre con una pregunta acerca de los usos de las imágenes, acerca de las instituciones que definen dichos usos, y acerca de las subjetividades que surgen de dicho proceso.

Más aun, al reflexionar acerca del rol de una imagen al interior de una institución y de una red de poder determinada, Farocki plantea necesariamente la pregunta sobre las modificaciones históricas de la función social de las imágenes. En particular, su obra se concentra en el paso desde un régimen disciplinario hacia aquello que Deleuze ha definido como sociedades de control (Farocki 210) ${ }^{11}$. A nivel de representación visual, este paso es acompañado por el desplazamiento desde el régimen de la imagen hacia un nuevo régimen de la visualidad. La diferencia central entre ambos regímenes es que mientras la imagen se sostiene siempre sobre un juego de carencia y exceso (la representación de aquello que no está presente y el plus-valor de información que

de poder" y "la multiplicación de los efectos de poder gracias a la formación y a la acumulación de conocimientos nuevos" (227). De igual modo, en los trabajos de Harun Farocki este doble proceso entre saber y poder se manifiesta permanentemente en las diversas imágenes operativas: una nueva tecnología de la imagen es inmediatamente una nueva fuente de saber; todo saber es a su vez una herramienta que permite perfeccionar el ejercicio del poder.

11 Este paso desde la disciplina al control respondería, a su vez, a un giro desde la producción industrial hacia la producción posindustrial. Es importante tener presente dicho giro ya que permite comprender el rol activo que adquieren las imágenes operativas al interior del nuevo régimen de producción. Véase la hipótesis de Christian Marazzi respecto al giro lingüístico de la economía y la política en el capitalismo posindustrial. 
dicha ausencia genera), lo visual contiene en sí mismo la totalidad de información que ella puede y necesita contener. Las imágenes operativas formarían parte fundamental de este giro hacia la visualidad: las imágenes operativas aparecen como imágenes puramente instrumentales, sin ninguna propiedad visual o valor estético producido intencionalmente (Tomas 233).

Según Rodowick, la obra de Farocki define una nueva filosofía de la visualidad según la cual la imagen aparece como una superficie "que contiene toda la información que ésta puede y podrá llegar a contener; nada en una imagen está ausente o es invisible" (195). A diferencia de las imágenes no-operativas, las imágenes operativas de Farocki no representan un objeto, más bien forman parte de un procedimiento técnico. En este sentido, no existe un juego de carencia y exceso que delimite el valor de la representación, sino que la imagen debe contener la totalidad de la información necesaria para el procedimiento técnico para el cual fue producida.

Para examinar las implicancias de este pasaje desde la imagen hacia la visualidad es necesario explorar un segundo concepto que define la obra de Harun Farocki: el montaje blando (soft-montage). Esto nos permitirá profundizar el análisis de la noción de imágenes operativas, así como también el examen del potencial crítico de su trabajo audiovisual.

\section{Montaje blando}

La noción de montaje blando es utilizada por Farocki en relación a sus video-instalaciones de proyección doble ${ }^{12}$. Según escribe él mismo, en la proyección doble "hay sucesión y simultaneidad, el vínculo de una imagen con la siguiente y con la de al lado. Un vínculo con lo previo y lo simultáneo" (111). El montaje que se produce en la proyección doble entre elementos paralelos (y ya no solo entre elementos sucesivos) es lo que él llama montaje blando. En el montaje blando "una imagen no toma el lugar de la precedente, sino que la complementa, la reevalúa, la pone en equilibrio" (Phantom 302).

Un referente importante del concepto de montaje blando lo encontramos en la noción de "poli-visión" propuesta por Abel Gance en su película Napoleón de 1927. En la secuencia final de esta película, Gance utilizó un sistema de proyección de tres pantallas montadas horizontalmente. Su objetivo era superar la "imagen fragmentada" y conseguir un estado de "híper-hipnosis" para lograr la "identificación total" del espectador con la imagen cinematográfica (Bellour 418) ${ }^{13}$. No obstante, Gance

12 La primera instalación de doble pantalla de Harun Farocki fue Interface (1995), en la cual Farocki reflexiona explícitamente sobre su trabajo documentalista, comparando la mesa de edición con la doble proyección de la instalación. A partir del año 2000, el formato de doble proyección se torna el formato preferido por Farocki para la mayoría de sus obras.

13 Para un análisis de la polivisión en el cine de Abel Gance y su relación con el "cine expandido" véase el texto Of An Other Cinema de Raymond Bellour. 
nunca quedó satisfecho con este procedimiento debido a la imposibilidad técnica de desaparecer la huella dejada por el espacio de las tres telas entre sí. En el caso del montaje blando de Farocki, también se trata de una polivisión. La diferencia, sin embargo, es que él no busca generar un estado de híperhipnosis. Por el contrario, el objetivo de su montaje blando es, precisamente, hacer visible el espacio entre ambos monitores, dando así representación espacial al intervalo temporal entre toma y toma, tematizando visualmente el problema del corte en tanto sustento de la producción de sentido cinematográfico. Al tematizar el problema del intervalo, el montaje blando permite avanzar en el análisis de las imágenes operativas y de la diferencia entre el régimen de la imagen y el de la visualidad.

Según David Tomas, la noción de montaje blando en Farocki debe ser leída en relación al concepto de intervalo en el cine de Dziga Vertov (250). En el manifiesto "We" de 1919, Vertov introduce su teoría del intervalo. Para él, el cine constituye el arte de inventar y organizar movimientos (y su rechazo del cine narrativo se debe principalmente a que en este el movimiento es subordinado a la acción dramática). Más aun, es el intervalo, el corte entre plano y plano, el que permite en el cine, a través del montaje, inventar y organizar los movimientos: "El intervalo (la transición de un movimiento a otro) es el material, el elemento a través del cual se organiza el arte del movimiento. Es el intervalo el que permite que el movimiento alcance su resolución kinésica" (Vertov 8). Esto quiere decir que el movimiento se produce principalmente entre los planos y no en su interior (Petric 35).

Según algunos autores (Blümlinger, "Memory" 107; Petric 35), la noción de intervalo en Vertov proviene de la teoría de la música: en la música, el intervalo funciona como la brecha entre dos elementos que hacen posible la aprehensión de su diferencia. Dicho de otro modo, sólo tenemos notas musicales porque existe una brecha en el flujo musical. De igual forma, en el cine tenemos verdadero movimiento, es decir, conflicto entre elementos diversos, gracias al intervalo entre uno y otro plano. Por lo tanto, el intervalo en el cine no debe ser entendido en términos negativos como aquella brecha que separa dos tomas, sino en términos positivos como aquello que posibilita la unión de elementos heterogéneos y por ende la producción de una relación que, de no ser por el intervalo, no podría existir. ${ }^{14}$

14 Gilles Deleuze otorga especial atención en la noción de intervalo en Vertov y la conecta con el fundamento bergsoniano de su teoría del cine. Para Deleuze, el intervalo es aquella interrupción que permite que algo acontezca al interior de la inmanencia que constituye el movimiento. Al interior del plano de inmanencia, es decir, al interior de ese conjunto de imágenes-movimiento que compone la luz en el espacio, "aparece un intervalo, una desviación entre la acción y la reacción. Bergson no pide más: movimientos, e intervalos entre movimientos que servirán de unidades (exactamente lo mismo que demandará Dziga Vertov, cuya concepción del cine era materialista)" (94). Más aun, Deleuze repite la definición del intervalo de Vertov: "el intervalo no será ya lo que separa una reacción de la acción recibida, lo que mide la inconmensurabilidad y la imprevisibilidad de la reacción, sino por el contrario lo que, dada una acción en un punto del universo, encontrará la reacción apropiada en otro punto cualquiera y por distante que esté" (123). Y luego concluye que "la originalidad de la teoría vertoviana del intervalo estriba en que éste ya no indica el abrirse de una desviación, la puesta en distancia de dos imágenes consecutivas, sino, por el contrario, la puesta en correlación de dos imágenes lejanas (inconmensurables desde el punto de vista de nuestra percepción humana)" (123). 


\section{FIGURA 3}

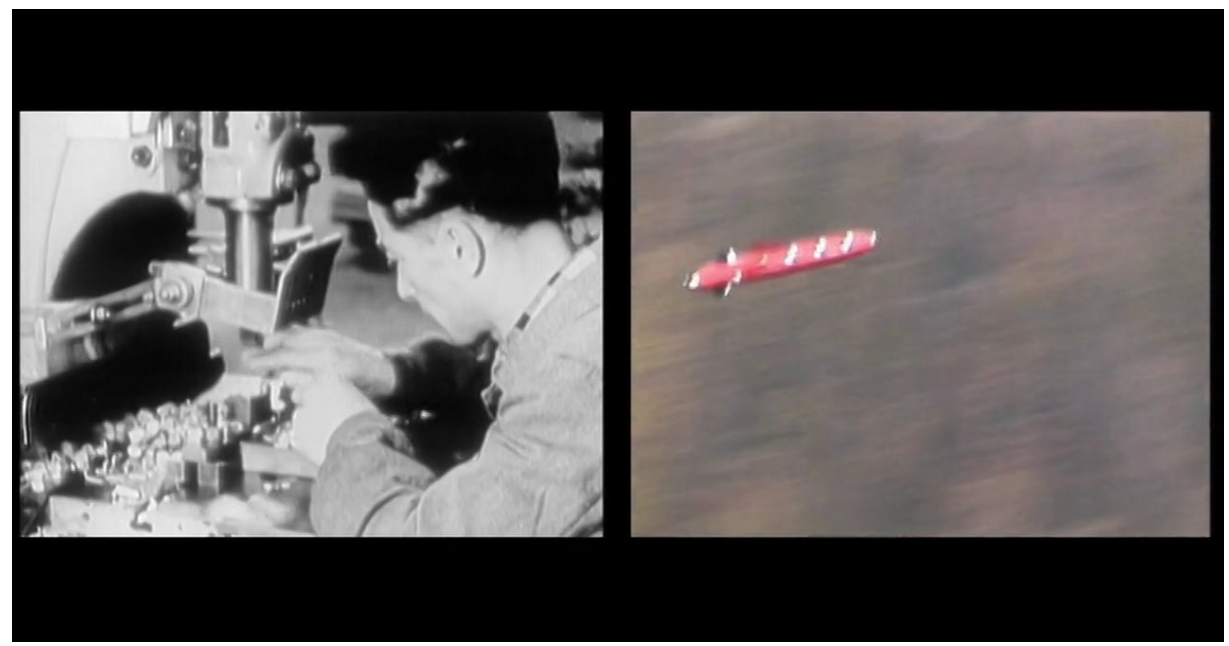

Eye/Machine II, Harun Farocki. Video-instalación de proyección doble. 2002.

Según la teoría vertoviana, el intervalo sería la base de toda producción de sentido cinematográfico. Con la hegemonía del cine narrativo, no obstante, el intervalo es capturado por el plano/contraplano, subordinando la potencia del arte cinematográfico a la mera representación dramática. Con el cine narrativo, el plano/contraplano se convierte en lo que el propio Farocki ha denominado "la expresión más importante de la ley del valor cinematográfico" (Desconfiar 83). Bajo la sombra de esta ley, el intervalo pierde su potencia como articulador de movimiento y de relaciones entre elementos heterogéneos, reduciendo el medio cinematográfico a la trasmisión de una fábula dramática. Farocki escribe:

Plano/contra-plano significa: vemos la imagen de una cosa y luego la imagen de lo que está enfrente. Dado que el cine está compuesto en un ochenta por ciento de situaciones dialógicas, por lo general vemos a una persona mirando a la derecha y luego a otra mirando hacia la izquierda, etc. También puede ocurrir que la primera persona apunte hacia la izquierda un revólver y la segunda persona levante las manos en dirección a la derecha o que una mujer sonría hacia un lado y aparezca un hombre del otro demostrando emoción por la sonrisa (83).

Más aun, Farocki sostiene que "el procedimiento del plano/contra-plano es un procedimiento del montaje que, sin embargo, repercute en el procedimiento de filmación, por lo tanto también en las ideas, en la selección y en el uso de las imágenes y lo que precede a la imagen. En definitiva, el plano/contraplano es la primera regla, la ley del valor" (83). Por lo tanto, que el plano/contraplano sea la primera ley del valor cinematográfico significa que define el fundamento de la producción de valor a través de la imagen cinematográfica: "El plano/contra-plano es una figura lingüística tan im- 
portante porque permite unir de forma sucesiva imágenes muy distintas entre sí. Hay continuidad y ruptura, el curso se interrumpe y, sin embargo, se avanza" (84). El uso del plano/contra-plano es tan hegemónico en el cine narrativo que, aún en su ausencia, funciona como medida del valor. En el caso de Sin aliento (1960) de Jean-Luc Godard, por ejemplo, los jump-cuts se hacen visibles precisamente por la ausencia del plano/ contra-plano. Más aun, estos jump-cuts "llaman la atención sobre algo que en el cine pocas veces queda en primer plano: que los cortes estructuran el texto" (Farocki 87).

En suma, este breve desvío por las nociones de intervalo y de plano/contra-plano nos permite volver a los conceptos de montaje blando y de imágenes operativas en Farocki. Como propone Christa Blümlinger, una de las características centrales de las imágenes operativas es la total ausencia del plano/contraplano ("Memory" 103). Las imágenes producidas por una cámara de seguridad o las imágenes de un avión de reconocimiento, por ejemplo, no responden al lenguaje del plano/contraplano sino que contienen ellas mismas la totalidad de la información necesaria para cumplir la función para la que fueron producidas. Por ello mismo, se puede decir que en las imágenes operativas es precisamente el intervalo temporal el que está ausente. Más aun, Christa Blümlinger utiliza esta ausencia de plano/contraplano y de intervalo en las imágenes operativas para definir la diferencia entre el régimen de la imagen y el régimen de lo visual ("Harun" 315).

Uno de los primeros autores en hablar acerca de la distinción entre imagen y visualidad fue Regis Debray en su libro Vida y muerte de la imagen. Allí Debray propone tres edades de la representación visual: la edad de la mirada mágica, la edad de la imagen y la edad de la visualidad (38-9). Además, a diferencia de la imagen que hace presente lo ausente:

$$
\begin{aligned}
& \text { lo visual es la verificación óptica de que las cosas están funcionando a un nivel } \\
& \text { meramente técnico: no hay contra-planos, nada falta, todo está sellado en un } \\
& \text { circuito cerrado, un poco como el espectáculo pornográfico que no es otra cosa } \\
& \text { que la verificación extasiada de que los órganos funcionan. Lo opuesto ocurre } \\
& \text { con la imagen -la imagen que hemos adorado en la sala de cine hasta un punto } \\
& \text { obsceno. La imagen siempre ocurre en el punto de encuentro entre dos fuerzas; } \\
& \text { su propósito es atestiguar una cierta alteridad, y si bien la esencia se encuentra } \\
& \text { siempre allí, algo está siempre ausente. La imagen es simultáneamente más y } \\
& \text { menos que sí misma (cit. en Blümlinger, "Harun” 315). }
\end{aligned}
$$

La imagen operativa se distingue de la imagen no-operativa tal como la visualidad respecto de la imagen: mientras la segunda depende siempre de una relación de exceso/carencia con la información fuera de la imagen, la primera contiene toda la información necesaria para su funcionamiento. A partir de la noción de intervalo, podemos agregar que si toda imagen operativa siempre contiene toda la información que puede abarcar (Rodowick 195), entonces será el corte el responsable de introducir el exceso/carencia que distingue la imagen operativa de la no-operativa. Y si 
la ausencia y el exceso, que definen el régimen de la imagen, es siempre el resultado de un intervalo, entonces Farocki utilizará el montaje blando para reintroducir el intervalo en las imágenes operativas (representando espacialmente el corte y el plano/ contraplano como elementos constitutivos de la producción de valor audiovisual) y con ello devolverlas del régimen de la visualidad al régimen de la imagen.

Para concluir el análisis de las imágenes operativas volvamos brevemente a la filosofía del lenguaje de Austin. Luego de sostener sistemáticamente a través de todas sus conferencias la distinción entre uso constatativo y uso performativo del lenguaje, Austin toma un giro para proponer que los actos performativos no constituyen un caso excepcional del lenguaje sino que de hecho definen el carácter básico de todo acto comunicativo (193-4). En su décima conferencia, menciona que, por un momento, es necesario olvidarse "de la distinción inicial entre realizativos y constatativos" e intentar buscar un nuevo comienzo desde donde analizar "los sentidos en los que decir algo es hacer algo" (166). De ese modo, plantea, resulta evidente que toda expresión posea un sentido locucionario (su significado), un sentido ilocucionario (una fuerza al decir algo) y un sentido perlocucionario (los efectos que busca lograr) (166). Entonces, a partir de esta triple distinción, cada vez que nos referimos al uso descriptivo o constatativo de un enunciado (aquella forma del lenguaje que puede ser reducida a su valor de veracidad) estamos llevando a cabo un proceso de abstracción que extrae un acto de comunicación de sus aspectos ilocucionarios y perlocucionarios (192-3). Lo que se hace necesario, por lo tanto, no es una filosofía del lenguaje que explore las diferencias entre el carácter descriptivo y el carácter performativo del lenguaje, más bien es el análisis exhaustivo de las fuerzas ilocucionarias detrás de todo acto de comunicación (197).

Si desplazamos el análisis de Austin hacia la obra de Farocki lo relevante sería, entonces, realizar un análisis exhaustivo de las fuerzas ilocucionarias de las imágenes en sus diversas funciones sociales. Y esto es precisamente lo que define el mérito tanto de su obra como de su noción de imágenes operativas: el análisis de las transformaciones históricas que ha tenido la función social de la imagen. Más aun, gracias a la noción de montaje blando, podemos sostener que el intervalo es el que determina la distinción entre imagen operativa e imagen no-operativa; entre el uso narrativo, referencial de una imagen, y su uso no narrativo (no-referencial); entre el régimen de la imagen y el régimen de lo visual.

Por esta razón, las nociones de imágenes operativas y de montaje blando van, por general, de la mano en el cine de Farocki. Es, precisamente, cuando gira por completo hacia el análisis de las imágenes operativas que comienza a utilizar estrictamente el formato de la proyección doble, y con ello a construir operaciones de montaje blando. En el documental Imágenes de prisión (2000), por ejemplo, aún coexisten imágenes operativas (imágenes producidas por cámaras de seguridad y por dispositivos de vigilancia) con imágenes no-operativas (imágenes provenientes de las diversas representaciones de la cárcel en el cine narrativo y documental). En la video-instalación de proyección doble exhibida el mismo año, Creo que veía a prisioneros, descarta toda 
imagen no-operativa utilizada en el documental Imágenes de prisión, estableciendo con ello una complicidad interna entre las nociones de imagen operativa y de montaje blando que caracterizará de ahí en más el desarrollo de su obra.

\section{Conclusión: sobre el valor crítico del metraje encontrado en Harun Farocki}

La obra audiovisual de Farocki pertenece en gran medida a lo que ha denominado como cine de metraje encontrado (found-footage), es decir, la producción de una obra audiovisual a través del montaje de un material audiovisual reciclado. Como propone William Wees, el valor crítico de este tipo de cine es que extrae a las imágenes de su consumo inmediato, irreflexivo, y las hace aparecer en tanto imágenes, "como el producto de la industria televisiva o cinematográfica, y con ello, como piezas del vasto y complejo mosaico de información, entretenimiento, y persuasión que constituye nuestra vida moderna, saturada por los medios de comunicación masivos" (32). Como podemos ver, Wees limita su análisis a las imágenes provenientes de los medios de comunicación de masas, ignorando la existencia de aquello que Farocki llamó imágenes operativas. En el trabajo de reciclaje realizado por Farocki, las imágenes siempre aparecen en tanto resultado de un proceso de producción institucional inseparable de un diagrama de poder. Dicho de otro modo, en su trabajo el metraje encontrado posibilita una crítica de las imágenes no en su sentido referencial sino en tanto dispositivo, es decir, como un aparato de producción institucional que en cada caso da sostén a un mundo determinado. Cuando decimos que el potencial crítico del trabajo de Farocki consiste en desarrollar una reflexión acerca de la historicidad de los usos sociales de la imagen, no entendemos "uso" desde una perspectiva utilitaria (como una herramienta que permite un uso específico), sino a través de la noción de dispositivo: la imagen en tanto dispositivo que determina una experiencia concreta del mundo. De este modo, no es solamente tematiza e historiza los usos de las imágenes, sino que establece una reflexión sobre el modo en que sujeto y objeto son construidos tanto por los diversos dispositivos técnicos como por la red institucional que sostiene los usos de la imagen.

Por ello, las video-instalaciones de Harun Farocki combinan el reciclaje de imágenes operativas con el montaje blando e introduce el corte (el intervalo) en el flujo infinito de imágenes operativas en tanto operación crítica de su trabajo. Con ello, devuelve el flujo de imágenes operativas desde el régimen de la visualidad hacia el régimen de la imagen. El montaje blando reintroduce la dialéctica de la carencia y el exceso en las imágenes operativas, forzando al espectador a preguntarse por la nueva producción de sentido producida por el montaje (tanto simultáneo como secuencial) ${ }^{15}$.

15 Según Christa Blümlinger ("Harun" 321), las video-instalaciones de Farocki funcionan como "ready-mades" en los cuales las imágenes operativas son desplazadas desde la esfera de la utilidad hacia la esfera de la contemplación. En el trabajo de Farocki, el montaje blando hace visible el "valor exhibitivo" de las imágenes operativas. 


\section{FIGURA 4}

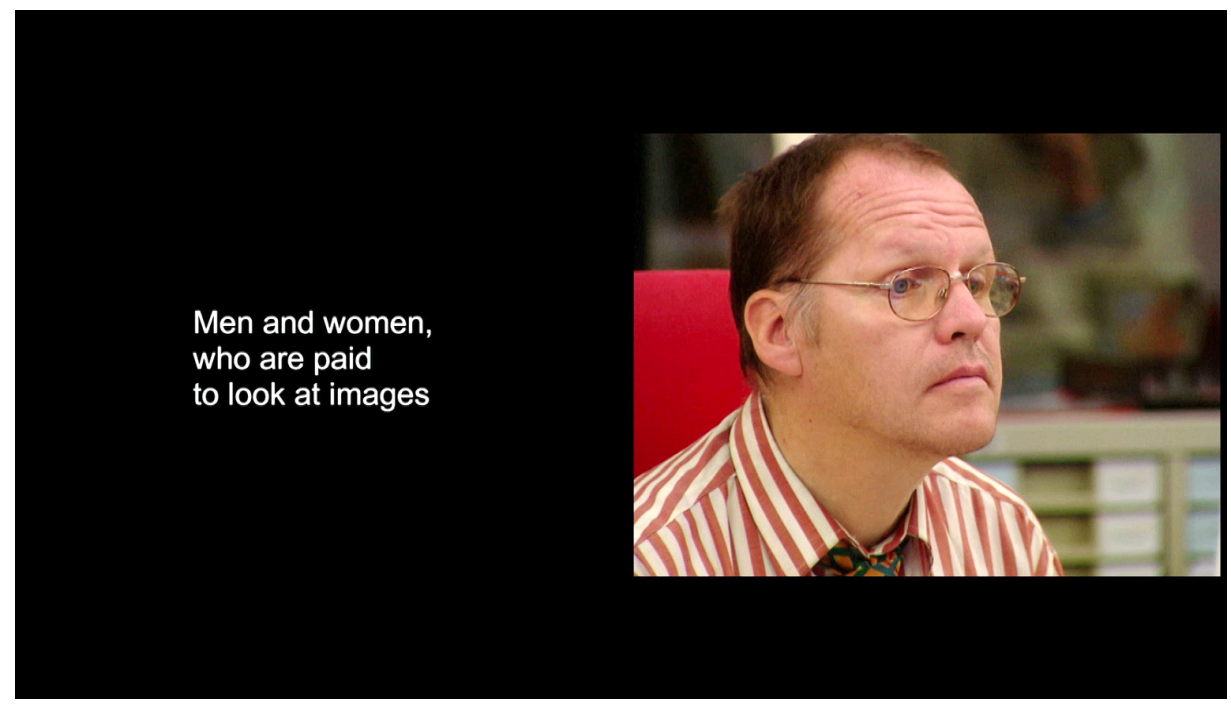

Counter-Music, Harun Farocki. Video-instalación de proyección doble. 2004.

Como propone Blumenthal-Barby, la pregunta acerca de cómo Farocki reintroduce un potencial crítico en las imágenes operativas pasa necesariamente por la técnica del montaje blando y por la distinción entre el ojo humano y la visión maquínica:

a diferencia del procesamiento algorítmico de imágenes que opera de forma automática en la visión maquínica, la manipulación de imágenes llevada a cabo por Farocki permanece completamente dependiente de un ojo y de una imaginación humanos. De este modo, el trabajo de Farocki se mueve en una dirección opuesta a la de las imágenes operativas, las cuales avanzan progresivamente hacia la expulsión del ojo humano de todo proceso productivo [...] Farocki toma imágenes operativas, que no fueron destinadas a ningún espectador, y las inserta en el museo, devolviéndolas a la esfera de la contemplación (344).

La potencia crítica de su trabajo consiste en que desplaza las imágenes operativas desde la esfera de una función técnica hacia la esfera de la contemplación, y desde el mundo de la visión maquínica hacia el mundo de la visión humana. En CounterMusic (2004), por ejemplo, pone en pantalla una serie de imágenes operativas que se utilizan para administrar técnicamente la ciudad de Lille, Francia. Dichas imágenes, que nunca fueron destinadas a ser objeto de contemplación, son montadas junto a las imágenes de la ciudad retratada por Dziga Vertov en El hombre de la cámara y por Walter Ruttmann en Berlín, Sinfonía de una ciudad. Con ello, establece un punto de contraste entre dos edades y dos funciones de la imagen. Mientras que en el caso de Vertov y Ruttmann la imagen de la ciudad tenía por destino a un espectador, en 
el caso de Farocki, la ciudad de Lille es retratada a través de imágenes que no sólo no fueron producidas para la contemplación, sino que, en su mayoría, ni siquiera tenían por destino un ojo humano. Como propone Michael Cowan (2008), Counter-Music da cuenta de la siguiente contradicción: por un lado, la red de cámaras de vigilancia y de control de la ciudad de Lille ha realizado efectivamente el sueño de Vertov: ha hecho de la ubiquidad visual una posibilidad técnica real; sin embargo, al mismo tiempo, dicha materialización del sueño de representabilidad total de la ciudad ha sido posible solo en la medida en que la mano y el ojo humano han sido excluidos del proceso de representación, reemplazados por cámaras automáticas y software de procesamiento de imágenes. De este modo, en Counter-Music Farocki devuelve las imágenes operativas a la esfera del ojo humano precisamente para dar cuenta de las contradicciones que definen el estatuto contemporáneo de la imagen.

El valor crítico de la obra de Farocki es indisociable de una reflexión sobre el paso de una sociedad industrial a una sociedad posindustrial. En la obra de Farocki, esta reflexión incluye tres niveles: el paso de un diagrama a otro del poder (de la sociedad disciplinar a la sociedad de control), el paso de un régimen a otro de la imagen (de la imagen a la visualidad), y la progresiva desaparición del trabajo humano de la esfera productiva (y la consecuente emergencia de una visión maquínica). Más aun, estos tres niveles se encuentran completamente vinculados entre sí, lo que quiere decir que para comprender el pasaje de una sociedad disciplinar a una de control (y por ende de la sociedad industrial a la posindustrial), la distinción entre imagen y visualidad y el concepto de imágenes operativas se hacen fundamentales (Blümlinger, "Memory" 108-9). Al mismo tiempo, el montaje blando y su capacidad para introducir el intervalo en el flujo infinito de imágenes operativas le permiten a Farocki analizar de manera específica la historicidad de la función social de las imágenes y su estatuto en las sociedades contemporáneas.

\section{Referencias}

Austin, John. Cómo hacer cosas con palabras. Barcelona: Paidós, 1990. Impreso.

Barthes, Roland. Mitologías. Madrid: Siglo xxi, 2000. Impreso.

Baudrillard, Jean. "Hacia una crítica de la economía política del signo". Crítica de la economía política del digno. Buenos Aires: Siglo xxI, 2005. 166-93. Impreso.

Bellour, Raymond. "Of an Other Cinema". Art and the Moving Image. Ed. Leighton, Tanya. Londres: Tate, 2008: 406-22. Impreso.

Blumenthal-Barby, Martin. “'Cinematography of Devices': Harun Farocki's Eye/Machine Trilogy”. German Studies Review 38.2 (2015): 329-51. Impreso.

---. “Counter-Music: Harun Farocki's Theory of a New Image Type”. October 151 (2015): 128-150. Impreso. 
Blümlinger, Christa. "Harun Farocki: Critical Strategies”. Harun Farocki: Working on the Sight Lines. Ed. Thomas Elsaesser. Amsterdam: Amsterdam University Press, 2004. Impreso.

---. "Memory and Montage: On the Installation Counter-Music". Harun Farocki: Against What? Against Whom? Eds. Antje Ehmann y Eshun Kodwo. Londres: Koenig Books, 2009. Impreso.

Cowan, Michael. "Rethinking the City Symphony after the Age of Industry: Harun Farocki and the 'City Film”'. Intermédialités 11 (2008): 69-86. Impreso.

Daney, Serge. "Before and after the Image". Discourse 21.1 (1999): 181-90. Impreso.

Debray, Regis. Vida y muerte de la imagen: Historia de la mirada en occidente. Barcelona: Paidós, 1994. Impreso.

Deleuze, Gilles. La imagen-movimiento: Estudios sobre cine 1. Barcelona: Paidós, 1984. Impreso.

Ehmann, Antje \& Eshun Kodwo, eds. Harun Farocki: Against What? Against Whom? Londres: Koenig Books, 2009. Impreso.

Elsaesser, Thomas, ed. Harun Farocki: Working on the Sight Lines. Amsterdam: Amsterdam University Press, 2004. Impreso.

Farocki, Harun. Desconfiar de las imágenes. Buenos Aires: Caja Negra, 2015. Impreso.

---. "Phantom Images". Public 29 (2004): 12-24. Impreso.

Fernández, Diego, ed. Sobre Harun Farocki: la continuidad de la Guerra a través de las imágenes. Santiago: Metales Pesados, 2012. Impreso.

Foucault, Michel. La verdad y las formas jurídicas. Barcelona: Gedisa, 1999. Impreso.

---. Vigilar y castigar: Nacimiento de la prisión. Buenos Aires: Siglo xxI, 2002. Impreso.

Lyotard, Jean Francois. La condición postmoderna: Informe sobre el saber. Madrid: Cátedra, 2000. Impreso.

Machado, Arlindo. Pré-Cinemas \& Pós-Cinemas. São Paulo: Papirus, 2007. Impreso.

Petric, Vlada. "Dziga Vertov as Theorist". Cinema Journal 18.1 (1978): 29-44. Impreso.

Rodowick, D. N. "Eye Machines: D. N. Rodowick on the Art of Harun Farocki". Artforum International 53.6 (2015): 190-97. Impreso.

Tomas, David. Vertov, Snow, Farocki: Machine Vision and the Posthuman. Nueva York, Londres: Bloomsbury, 2013. Impreso.

Vertov, Dziga. Kino-Eye: The Writings of Dziga Vertov. Berkeley: University of California Press, 1984. Impreso.

Virilio, Paul. The Vision Machine. Indianapolis: Indiana University Press, 1994. Impreso.

Wees, William. Recycled Images: The Art and Politics of Found Footage Films. Londres: Anthology Film Archives, 1993. Impreso.

Recibido: 10 junio 2016

Aceptado: 22 septiembre 2016 